\title{
Proceeding
}

Supplementary Issue: Spring Conferences of Sports Science. International Conference on Psychology of Education Sciences \& Lifestyle.

\section{The methodology of the approach to improving the system of end-to-end training and selection in the Russian national sport - sambo (self-defence without weapons)}

\author{
I. R. SHEGELMAN , A. N. GODINOV
}

Petrozavodsk State University (PSU), Petrozavodsk, Republic of Karelia, Russian Federation

\begin{abstract}
In recent years, in many countries of the world, attention to the Russian national sport - sambo (self-defense without weapons) has increased. Two major versions, developed by the International and European Federations, are officially recognized in the world: sports sambo and combat sambo. The paper considers the methodology of the approach to improving the system of end-to-end training and selection in sambo. The experience of implementing this approach, obtained at the Sambo School of the Republic of Karelia, is considered. Thanks to this sambo training, many children and adolescents are enrolled in schools in the region. Highly qualified athletes (World, Europe, Russia champions) are trained at the supporting university of the Republic of Karelia - Petrozavodsk State University, youth are being prepared for military service, sambo elements are used in physical training of employees of various power structures.

Keywords: Painful techniques; Throws; Sport; Martial arts; National sport; Sambo; Selection in sport; Longterm training.

\section{Cite this article as:}

Shegelman, I.R., \& Godinov, A.N. (2020). The methodology of the approach to improving the system of endto-end training and selection in the Russian national sport - sambo (self-defence without weapons). Journal of Human Sport and Exercise, 15(3proc), S973-S986. doi:https://doi.org/10.14198//hse.2020.15.Proc3.49
\end{abstract}

Corresponding author. Petrozavodsk State University (PSU), 33, Lenina pr., 185910, Petrozavodsk, Republic of Karelia, Russian Federation.

E-mail: denis.sharapova@bk.ru

Supplementary Issue: Spring Conferences of Sports Science. International Conference on Psychology of Education Sciences and Lifestyle.

JOURNAL OF HUMAN SPORT \& EXERCISE ISSN 1988-5202

(c) Faculty of Education. University of Alicante

doi:10.14198/jhse.2020.15.Proc3.49 


\section{INTRODUCTION}

In Russia, sambo training is conducted under the state-supported projects Sambo to Schools, Sambo to the Ready for Labor and Defense system(RLD), and Sambo to Higher Education Institutions. Special elements of sambo are trained by police and military personnel, including for detention and protection from criminals (Suleymanov, 2016). Given all this, sambo training is a very complicated process. The paper considers the methodology of the approach to improving the system of end-to-end training and selection in the Russian national sport - sambo (self-defense without weapons). The experience of implementing this approach, obtained at the Sambo School of the Republic of Karelia, is considered. Thanks to this sambo training, many children and adolescents are enrolled in schools in the region and at the supporting university of the Republic of Karelia - Petrozavodsk State University, highly qualified athletes (world, European, Russian champions) are trained, youth are being prepared for military service, sambo elements are used for physical training of employees various power structures.

The scientific literature widely covers the issues of improving the long-term training of athletes in various sports, including sambo and judo.

It was shown in (Platonov \& Bolshakova, 2013) that the realization of sports talent and the achievement of a high level of skill by an athlete is possible only with the systematic long-term training, optimal for a particular sport and the age of the athletes. Forced training and overly early specialization, violating the foundations of the rational construction of many years of training, are unacceptable.

To increase the effectiveness of managing the long-term training of athletes, a scientific justification of the ways to improve the motor qualities and abilities that are significant for sports performance, as well as the individualization of the training process, is necessary (Levitsky, 2003; Sepehri and Sheikhalizadeh, 2019).

Studies of the athletes' preparedness according to pedagogical observation and biomedical control (Talibov, Gushchina, Lyashenko \& Dmitrieva, 2019) among highly qualified athletes did not reveal in most of them negative changes in their state of health under the influence of intense long-term sports training.

Martynenko A.N. (2002) examines the mental processes of sambo athletes 10-12 years old and believes that the leading ones are motivation for success, imagination, quick thinking, random access memory, selfregulation of emotions, distribution and switching of attention; determination.

The authors analyzed the use of simulators in the training of sambo wrestlers (Shegelman, Kirilina \& Godinov, 2019). Among the patented methods of selecting adolescents for martial arts is work (Mamaev, Zakamensky, Poleyschikov \& Rozhentsoy, 10.02.2015). The device for monitoring and evaluating vestibular stability (Botyaev, 13.03.2017), patented by the Surgut State Pedagogical University, makes it possible to objectively assess the state of vestibular functions of both young and qualified athletes, especially in sports where high requirements for vestibular stability are imposed (difficult coordination, game, martial arts, etc.). The device is used in the selection and diagnosis of sports predisposition of children and adolescents, for this purpose, stage-by-stage model values of vestibular stability in certain sports have been developed.

Experts note that this did not happen by chance. The specifics of the transformation of socio-economic, environmental factors and a sharp decrease in the motor activity of the younger generation negatively affect the level of their physical and mental development. And adolescents, leading to a decrease in adaptation 
reserves, the occurrence of a mismatch in the mechanisms of regulation of functions, an increase in the number of chronic patients, in particular among the female contingent.

To organize the process of sports training in (Shilakin, 2004), to improve the skill of a sambo wrestler, it is recommended to improve the motor potential of a sambo wrestler while winning an attack grab already at the initial stages of sambo training.

Of interest is the development of Kaluga State University named after K.E. Tsiolkovsky (Alfimtsev, Korolev \& Yakushin, 04.12.2017). The development is aimed at improving the process of training athletes in conducting combat techniques without causing injury to real opponents. To this end, simulating attacks on vulnerable points on a human simulator is simulated. For this, the dummy design is used, the elements of which are equipped at pressure points imitating the enemy's weak points with pressure sensors.

The analysis showed that in the well-known studies, sufficient attention was paid to the long-term training of high-class athletes; new solutions are being patented for training sessions of martial artists, including sambo wrestlers. At the same time, a more detailed consideration of selection issues is required when practicing sambo, which provides a wider involvement of people who want to engage in a national sport - sambo (selfdefense without weapons) and excluding the possibility of psychological trauma if the selection is not properly organized.

\section{MATERIALS AND METHODS}

The purpose of the work is to study the state of research in the field of sambo development and give recommendations on improving the methodology of creating a system of end-to-end training and selection in the Russian national sport - sambo (self-defense without weapons).

The research objectives included:

- Analysis of the state of research in the field of improving the long-term training of athletes in various sports, including sambo and judo;

- Collection and analysis of materials in the field of patenting technical solutions to increase the effectiveness of training sessions of sambo wrestlers;

- Assessment of methodological approaches used in breeding in sports of high sports achievements and in youth sports, including sambo;

- $\quad$ Development of recommendations for improving the methodology of creating a system of end-toend training and selection in the Russian national sport - sambo (self-defense without weapons);

- Evaluation of the results of testing recommendations on the example of the Republic of Karelia.

As research materials, we used copyright materials of a detailed information search aimed at realizing the goal formulated above.

Particular attention is paid to the analysis of the results of dissertation research in the field of organizing longterm training sessions and breeding, including:

- Botyaev V.L. (2015). Scientific and methodological support of selection in sports based on the assessment of coordination abilities;

- $\quad$ Bulgakova, N. Zh. (1977). The problem of selection in the process of many years of preparation;

- Guba V.P. (1997). Age-related principles of the formation of sports skills in children in connection with the initial orientation in various sports; 
- Daev V. E (2007). Optimization of sports selection and orientation of football players by playing roles at the stage of in-depth specialization;

- $\quad$ Eganov A.V. (1999). Management of the training process to enhance the sports skills of judokas;

- Ivankin O.V. (2011). A comprehensive methodology for the formation of the optimal fighting state of young sambo wrestlers at the training stage;

- Kashkin A. A. The problem of the formation of special preparedness of young swimmers at the stages of long-term training;

- Levitsky A.G. (2003). Managing the process of training judokas taking into account the level of individual readiness for competitive activity;

- Litmanovich A.V. (1987). The structure of training loads in the physical training of young judokas at the stage of initial sports specialization, etc.

The work methodology provided for the evaluation of the results of testing the recommendations of the authors formulated with their participation on the example of the Republic of Karelia.

\section{RESULTS AND DISCUSSION}

An analysis of trends indicates the intensity of the development of sambo in Russia and the recognition of this type of martial arts in the world. This type of martial arts contributes to the development of physical, mental, intellectual and spiritual and moral qualities of persons engaged in sambo. This determines its high social significance in the education of children, adolescents, youth. It is no accident that Sambo is included in Russia in the Sambo to Schools, Sambo to Universities projects, elements of the national martial arts Sambo are included as additional standards for passing the TRP standards (Ivankin, 2011; Rapoport, 2015; Shegelman, 2015).

As noted in (Umarov, 2014), in the system of the educational and training process, a special place is occupied by solving the problem of the formation of motor skills and training influences, taking into account the individual typological characteristics of sambo wrestlers, including solving the problems of technical and tactical training of sambo wrestlers.

In recent years, close attention has been paid to the problem of attracting sambo to classes and the organization of the educational process of teaching sambo to children, boys, boys, girls and girls.

This problem is multidimensional and includes questions:

- $\quad$ Training and organizing the work of trainers;

- Selection for sambo exercises;

- Organization of pedagogical and psychological interaction of trainers with sambo-wrestling children, boys, boys, girls, girls;

- Organization of the training process;

- $\quad$ Training in techniques and tactics of sambo;

- $\quad$ Physical, psychological and moral-volitional development;

- Patriotic and moral education;

- Preparation for the competition;

- Pre-competitive training of highly qualified sambo fighters;

- Issues of recovery and development of motor and other skills;

- Combining educational and competitive processes with studies (work); 
- $\quad$ Study of the development experience of various types of martial arts, the techniques of which are used in sports sambo and combat sambo - judo, jujitsu, boxing, kickboxing, karate, hand-to-hand combat, etc;

- $\quad$ Issues of preparation for military service and work in power structures.

During the selection period to the sports section at the initial stage of sports training, the coach faces the most difficult task - anticipating (predicting) the sports future of a gifted child (teenager). This process is carried out on the basis of assessment using certain methods, criteria and/or intuition. With their use, the coach during the selection period tries to predict the possibilities of unlocking the potential of the child (adolescent) and, on this basis, decide whether or not to be enrolled in the sports section or school. After this, the coach and the young athlete will have a lot of work to do, according to the results of which the coach will be able to assess whether he made a mistake in his prediction, whether he lost not only his time and energy, but also the time and energy of the athlete due to the error. As noted, (Kokorina, 2007), sports selection during the selection of young men in sports schools is based on a forecast of 6-10 or more years in advance.

According to numerous studies, sports selection is one of the most important factors for achieving sports results (Volkov \& Filin, 1983; Seluyanov \& Shestakov, 2000; Sergienko, 2013; Gale lles et al.,, 2018). Naturally, various sports use different methods and criteria for sports selection. For example, in the monograph Sergienko L.P. (2013) considered the features of sports selection in athletics, gymnastics, figure skating, soccer, basketball, tennis, swimming, rowing, cycling, skiing, wrestling, boxing, fencing, weightlifting, powerlifting.

A significant amount of work has been devoted to the problem of selecting and predicting the sporting success of a particular teenager, girl, boy, girl in certain sports using special techniques and criteria:

- $\quad$ In acrobatics (Boloban \& Boloban, 2009);

- $\quad$ In aerobics (Kokorina, 2007);

- In basketball (Kopysova, 2002; Semenov, Sukhanova, Godunova,Irkhina \& Markina, 2016);

- In volleyball (Kudryashov, 2005);

- $\quad$ In kettlebell lifting (Pavlov, Tarasov \& Panina, 2008; Simen \& Drandrov, 2016);

- $\quad$ In rowing (Egorenko \& llyina, 2018);

- $\quad$ In game sports (Serova, 1999);

- $\quad$ In karate (Makaridin, 2006);

- $\quad$ In speed skating (Melikhova, 1986);

- $\quad$ In athletics (Kargin, 2006; Siris, Gaidarska \& Rachev, 1983);

- In table tennis (Barchukov \& Barchukova,2014; Aleksanyants, Grichanova, Dmitrenko \& Sabirova, 2012);

- In swimming (Bulgakova, 1977; Gogotova, Korneeva \& Polyakov, 2009; Davydov \& Aydienko, 2014; Kashkin, 2000);

- $\quad$ In polyathlon (Samsonov, 2011);

- $\quad$ In rugby (Danilova, 2006);

- $\quad$ In wrestling, in martial arts (Vinnichenko \& Kozlyakov, 2010);

- $\quad$ In gymnastics (Borschev, 2006; Medvedeva, Gaibov \& Terekhin, 2013);

- $\quad$ Orienteering (Yakushev, 2014);

- $\quad$ In sports games (Bril, 1980);

- $\quad$ In synchronized swimming (Larina, 1992);

- $\quad$ In race walking (Korolev, 2009); 
- In shooting (Medvedeva, Gaibov \& Terekhin, 2013; Saber \& Kublanov, 2009);

- In archery (Koval, 2012);

- In the field of tourism (Semenova, Tikhonov \& Yakov, 2013);

- In weightlifting (Suleymanov, 2016);

- $\quad$ In rhythmic gymnastics (Pavlova, 2008);

- In football (Dulibsky, 2010).

It should be noted that during the selection it is necessary to take into account the specifics of the disciplines in the nutra of the listed sports. So, for example, as Zatsiorsky notes, running and marathon running impose qualitatively different requirements on the body and cause the manifestation of different physical qualities (Zatsiorsky, 2009).

As noted by Afonina I.P. (2012), in the training process it is necessary to take into account that mastery of effective technique is much faster than the process of adaptation of musculoskeletal tissues and ligamentousarticular elements of wrestlers to growing loads and protection from exposure to factors. It must be borne in mind that underestimating this factor can cause a negative effect on the elements of the athlete's musculoskeletal system, including the shoulder joints, clavicular-acromial joints, cervical and thoracic spine of the wrestler.

It should be noted that attention to the selection for sambo classes is closely related to the expanded attention to issues of sports selection in various sports. For example, in (Kvashuk, Maslova \& Verlina, 2010), the need to use a set of organizational and methodological measures related to identifying the abilities of children and adolescents for specialization in a particular sport is noted.

In work (Peredelsky, 2016), it is noted that as early as 4-6 years old, children can identify, assess the presence or absence of a predisposition to playing sports in general and to playing specific sports.

As rightly notes Botyaev V.L. (2015) The selection problem is very complex for the following reasons. On the one hand, it is necessary to create conditions and attract the majority of the population to active sports. On the other hand, the number of athletes focused on sports of the highest achievements should be limited to those who, without prejudice to health, can withstand intensive training and competitive loads, achieving high results in sports. At the same time, access to sports should be expanded as part of a healthy lifestyle, and not just for competitions.

We believe that the work of specialists at Mari State University (Mamaev, Zakamensky, Polevschikov \& Rozhentsov, 10.02.2015), based on research (Babushkin, Shumilin \& Salakhov, 2009), reasonably expressed the opinion about the need for a high-quality selection of adolescents for martial arts (to which, as you know, Sambo fully applies). This is due to the fact that for martial arts athletes must have the skills to perform techniques in a short time with the necessary accuracy of movements to perform techniques. The specifics of the selection and special training of young athletes are considered in the work of Rapoport O.A. (2005).

Noting the great scientific and methodological work in the field of forming the scientific foundations of sports selection aimed at identifying sports talents, the authors consider it necessary to express the following position. 
The point is that, as noted in (Ostapenko \& Yankovskaya, 2014), in modern conditions, parents and children have the opportunity to independently choose the most appropriate schools and classes for teaching, focus on the best and most effective teachers.

At the same time, as a result of such selection, children began to be divided into capable, gifted and "rest". Such a system of sports education and selection has long been worked out by the best trainers in the world. In their work, such trainers achieve the highest sports results not only due to their unique coaching talent, but also due to the ability to predict the sporting success of their selected child (adolescent) for training. Already at the initial stage, they select from many only the most promising children from their point of view, and during the training, within the framework of a certain sports discipline, they continue to gradually select, leaving only the best of the best. We believe that without such an approach, they and their students would not have been able to achieve brilliant sporting results and climb the highest pedestals of their countries, the world, and the Olympic Games. Sufficiently tough selection allowed one of the authors to become an Honored Coach of Russia, to prepare prize-winners and champions of Russia, Europe, the World in Sambo, the second to become a master of sports in Russia and start coaching.

But at the same time, one cannot help but raise questions: "And where did the rest remain, and if they had not suffered the first psychological trauma during this kind of selection as a child, making it clear that they are "not the best", that they" did not take them", but simply "expelled." The acuteness of this problem is confirmed by the fact that at present coaches often work in multicultural sports teams, which also requires coaches to work with such teams (Godinov, 2015).

Considering the issues of selection in various fields of activity, including sports, it is necessary to pay attention to industrial psychotechnology, the definition of which is given in (Noskova, 2006): "industrial psychotechnics" is one of the branches of psychology that studies and optimizes labor, its products, processes, conditions of implementation, conditions the employee, his experiences, abilities, capabilities, to explain and purposefully change the behavior of people. The term "psychotechnics" was introduced at the beginning of the 20th century by the German psychologist William Stern (Stern, 1998). He developed the theory of "differential psychology" was aimed at identifying individual differences, the typology of people for predicting the characteristics of people's behavior in certain conditions and the results of their behavior and ways of targeted influence on the consciousness and behavior of a person based on the use of psychological knowledge about personality and individual psychological differences. The significance of the theory of William Stern is confirmed by studies of his work. For example, (Kushch, 2004; Sarjono et al., 2020) notes that the ideas of $\mathrm{V}$. Stern are at the heart of the modern approach to raising children and the formation of the child's selfawareness.

By the way, the pain of selection is felt not only by children, but also by adult athletes, when only the best of the best is selected for major competitions, and the rest remain at home on the "bench", possibly forever. Another selection problem for "age-old athletes", which is being replaced by young ones.

We believe that the solution to this psychological and socially complex problem is possible using three ways:

1. It is necessary to form not just great trainers, but trainers of a new formation, able to explain to the child that he is not the worst, that he is able to achieve results in other sports or in other types of future professional activities (in the field of digital technologies, engineering, IT communications, medicine, music, etc.), but you need to engage in sports for success in this professional activity;

2. You do not need to take the time of trainers according to paragraph "a", but use specially trained and trained "consultants"; 
3. It is necessary to create conditions so that people who have not undergone selection and are not in the main team can engage in a sport that has "pulled" them and try to prove that they are "no worse".

Let's consider two more of the listed ways.

The second way can be used based on Finnish experience. Let us dwell on it in more detail. In Finland, primary education counselors are student counselors or teacher educators. In high school, vocational schools and polytechnics, the term "student consultant" is used. A student advisor helps students plan their studies, apply for postgraduate studies and navigate their careers. The work of the consultant takes place in the classroom, in small groups, as part of individual lessons and through online tutoring. It includes information, organization of study and study trips, acquaintance with working life, informational and parental events. The consultant works with teachers, support staff, education providers, and many external schools. Personal guidance covers, for example, course and subject selection, study and life planning, career choice, and possible learning difficulties. It should be noted that all discussions with the student / student are confidential (Opinto-ohjaaja, oppilaanohjaaja). We believe that it is advisable to prepare such consultants from people with a pedagogical / psychological education for interaction with both teachers and their parents.

The third way is implemented by the Karelian Sambo Federation, which, together with the Ministry of Sports of the Republic of Karelia, systematically monitors the status of training and development of a national sport - Sambo and analyzes information on the status of the organization of work on the development of Sambo in the municipal districts and urban districts of the Republic of Karelia. The basic structures for the development of sambo in the region are Petrozavodsk State University (PetrSU) and the Sports School of the Olympic Reserve No. 5.

On January 25, 1969, the first university championship was held in PetrSU - the day that Karelian sambo fighters consider the day of foundation of republican sambo. Two years later, students in grades 7-8 began to be accepted into the student section, which later formed the backbone of the Karelia national team in sambo. First, the first candidates for the master of sports appeared, and then the masters of sports. Igor Varavva, now a sambo veteran, multiple world and European champion in sambo and judo among veterans, became the first master of sports of the USSR in sambo, after him Konstantin Lobanov, now a sambo trainer in the Murmansk region and Dmitry Efimov, now a judo coach, became masters of the USSR in Finland. During this period, graduates of PetrSU - sambo wrestlers began to disperse into the regions of Karelia and cultivate sambo in them. This ensured the influx of sambo schoolchildren to the educational institutions of Petrozavodsk, including Maxim Antipov, who came from the Karelian village of Pindushi, who became the repeated champion of Russia, the world champion in sambo, the champion of Finland in judo and Sergey Kamilov, who became the repeated champion of Russia and the world, the champion of Europe.

In Karelia, one of the first in the country, they began to cultivate combat sambo. As a result, in 2003, Karelian sambo wrestlers took the second team place in the championship of Russia, Maxim Antipov and Sergey Kamilov became champions. In 2008, at the Russian youth sambo championship, the national team of Karelia again took second place, four members of the national team of Karelia became champions, and one became a bronze medalist of the championship.

The active transformation of the development of the sambo system in the Republic of Karelia began in 2016. In 2018, the Municipal Budget Institution of the Petrozavodsk City District "Olympic Reserve Sports School No. 5" switched to a sports training program in sambo. In the Republic of Karelia more than 40 masters of sports of Russia, one Honored Master of Sports of Russia, three masters of sports of Russia of international 
class in sambo training, four World Champions, champions of Russia, winners of the Cups of Russia and the World have been trained. A coaching team was formed, including one Honored Coach of Russia and two Honored Coaches of Karelia. Currently, sambo in the Republic of Karelia is defined as a basic sport on the basis of order of the Ministry of Sports of Russia dated 01.08.2014 No. 664, the number of participants is more than 2000 people. Championships, Cups, Championships and stages of the All-Russian Sambo Competition are held annually. Athletes - members of sports teams of the Republic of Karelia travel to training camps, Championships, Cups and Championships of Russia.

Along with sports of the highest sportsmanship, attention has been strengthened to involving children and adolescents from primary school age in active sports. It should be noted that classes with them are of a healing nature using sambo elements for teaching skills to fall (insure) correctly, improving coordination and other motor and physical abilities. The best of these children and adolescents are transferred by trainers to the youth sports school, and later, with the manifestation of sports makings, they have the opportunity to get into the youth national team of the republic.

The republic annually for the first time in the country holds a traditional tournament of pre-conscription youth. In the Republic of Karelia, in order to attract schoolchildren and students to regular physical education and sports, to learn the basics of martial arts, to create conditions for the patriotic, physical and spiritual and moral education of the younger generation, the projects "Sambo to Schools" and "Sambo to Universities" are being successfully implemented, "Sambo in the RLD." The base organization for the Republic of Karelia for the implementation of these projects is PetrSU, where a specialized hall for conducting training sessions has been created and the implementation of the Sambo to Universities project has been launched for the first time in the country. The development of sambo training in Karelia is constrained by the state of the sambo infrastructure and a low level of funding for organizing training sessions, athletes traveling to competitions, and positioning Karelia as the basis for the development of sambo in the Northwestern Federal District of the Russian Federation. Petrozavodsk State University is today a reference university, a regional navigator in the research, innovation, educational and sports activities of the North-West region. It has a modern educational and sports infrastructure, and implements the main state and regional initiatives. It is a powerful innovative platform for the development and testing of such government projects as "Scientific and methodological support for the implementation of the All-Russian physical culture and sports complex in educational organizations implementing general and vocational education programs", "RLD to school", "Sambo to school", "Sambo in the RLD", having high scientific and methodological experience and potential, a developed sports infrastructure, the stability of the above projects remains. This is evidenced by the entry of PetSU into the National Student League Sambo. The university has also become a reference point in the training of students of PetrSU as athletes - sports of the highest achievements.

Today, the implementation of the Sambo project in Universities in PetrSU is carried out through the main subjects of interaction, this is an educational process. When organizing the educational process, a new system for the implementation of the discipline of coursework was built. It is planned to introduce elective courses established by the Federal State Educational Standards in all areas of PetrSU training, including Sambo. Specialists are being trained in the field of physical culture and sports, as well as life safety, the curriculum of which includes 72-hour course discipline "Theory and Methods of Sambo". As a result, graduates who are in demand not only in cities, but also in municipal settlements of the Republic of Karelia, are ready to show their professional competencies in sambo. They are ready to introduce elements into the educational environment (motor skills that form the technique of falling, insurance, self-insurance, keeping on a slippery surface) not only in sambo, but also in other sports. The schools of Karelia organized methodological and volunteer support of physical education teachers who implement elements of sambo in 
the classroom. Master classes are held for teachers of educational organizations. In 2020, a decision was made to create a Sambo branch on the basis of the School (technical school) of the Olympic reserve in the Karelian city - Kondopoga, which will certainly give a new impetus to the development of sambo in Karelia and attracting sambo athletes from the adjacent regions of the North-West of Russia to the republic for training.

\section{CONCLUSIONS}

An important place among the martial arts developed in the world is occupied by the Russian national sport - sambo (self-defense without weapons). In Russia, sambo training is conducted under the state-supported projects Sambo to Schools, Sambo to the Ready for Labor and Defense system, and Sambo to Higher Education Institutions. Special elements of sambo are trained by police and military personnel, including for detention and protection from criminals. Given all this, sambo training is a very complex multi-level process, and the method of selection and long-term training of sambo wrestlers requires constant development.

In recent years, close attention has been paid to the problem of attracting sambo to classes and organizing at the same time the educational process of teaching sambo to children, boys, boys, girls and girls. The analysis showed that in the well-known studies, sufficient attention was paid to the long-term training of highclass athletes; new solutions are being patented for training sessions of martial artists, including sambo wrestlers. At the same time, a more detailed consideration of selection issues is required when practicing sambo, which provides a wider involvement of people who want to engage in a national sport - sambo (selfdefense without weapons) and excluding the possibility of psychological trauma if the selection is not properly organized.

It is necessary to pay serious attention to the fact that during the selection (selection) in the sports section at the initial stage of sports training, the trainer must solve the difficult task of predicting the sports future gifted child (teenager) based on the assessment using certain methods, criteria and / or intuition his data during the selection period. It is necessary to predict the possibilities of unlocking the potential of this data and on this basis make a decision on whether or not to be admitted to the sports section or school. Sometimes, only based on the results of many years of work, the trainer will be able to assess whether he was mistaken in his prediction, whether he lost his time and energy and the time and energy of the athlete due to the error.

Noting the great scientific and methodological work in the field of forming the scientific foundations of sports selection aimed at identifying sports talents, the authors consider it necessary to state the following position. The fact is that, as noted in the work (Ostapenko \& Yankovskaya, 2014) in modern conditions, parents and children have the opportunity to independently choose the most appropriate schools and classes for teaching, focus on the best and most effective teachers. At the same time, as a result of such selection, children began to share on the capable, gifted and "others." Such a system of sports education and selection has long been worked out by the best trainers in the world. In their work, such trainers achieve the highest sports results not only thanks to the un a great coaching talent, but also due to the ability to predict the sporting success of the child (teenager) they select for training, at the initial stage they select from many of the most promising children from their point of view, and during the training they continue in stages within the framework of a certain sports discipline selection, leaving only the best of the best. Without such an approach, they and their students would not be able to achieve brilliant sporting results and climb the highest pedestals of their countries, the world, the Olympic Games. 
The solution of the psychological and socially complex problem of sports selection can be achieved in three ways. We need the formation of trainers of a new formation, able to explain to the child that he is not the worst, that he is able to achieve results in other sports or other types of future professional activities. 2 - you do not need to take the time of trainers, but use specially trained and trained "consultants". 3 - it is necessary to create conditions so that people who have not undergone selection and are not in the main team can engage in a sport that has "pulled" them and try to prove that they are "no worse".

The second way can be used based on Finnish experience. Let us dwell on it in more detail. In Finland, primary education counselors are student counselors or teacher educators. In high school, vocational schools and polytechnics, the term "student consultant" is used. A student advisor helps students or students plan their studies, apply for postgraduate studies and navigate their careers. The work of the consultant takes place in the classroom, in small groups, as part of individual lessons and through online tutoring. It includes information, organization of study and study trips, acquaintance with working life, informational and parental events. The consultant works with teachers, support staff, education providers, and many external schools. Personal guidance covers, for example, course and subject selection, study and life planning, career choice, and possible learning difficulties. It should be noted that all discussions with the student are confidential (Opinto-ohjaaja, oppilaanohjaaja). We believe that it is advisable to prepare such consultants from people with a pedagogical / psychological education for interaction with both teachers and their parents.

The third path is implemented by the Karelian Sambo Federation, which, together with the Ministry of Sports of the Republic of Karelia, systematically monitors the status of training and development of a national sport - sambo and analyzes information on the status of the organization of work on the development of Sambo in the municipal districts and urban districts of the Republic of Karelia. The basic structures for the development of sambo in the region are Petrozavodsk State University (PetrSU) and the Sports School of the Olympic Reserve No. 5. The paper considers the methodology of the approach to improving the system of end-to-end training and selection in the Russian national sport - sambo (self-defense without weapons). The experience of implementing this approach, obtained at the Sambo School of the Republic of Karelia, is considered. Thanks to this sambo training, many children and adolescents are enrolled in schools in the region and at the supporting university of the Republic of Karelia - Petrozavodsk State University, highly qualified athletes (world, European, Russian champions) are trained, youth are being prepared for military service, sambo elements are used for physical training of employees various power structures.

Training is being carried out for specialists in the field of physical education and sports, life safety, the curriculum of which includes the discipline of course training "Theory and Methods of Sambo" in the amount of 72 hours. Graduates who are in demand not only in cities, but also in municipal settlements of the Republic of Karelia, are ready to show their professional competencies in Sambo, introducing elements into the educational environment, as motor skills that form the technique of falling, insurance, self-insurance, keeping on a slippery surface, not only in this sport, but also in other sports. A sambo section has been created at the university, where both students of specialized areas of training and students of non-specialized areas of training are actively immersed in the ideology of this sport, and also form unique motor skills that will be useful to them in everyday life. The schools of Karelia organized methodological and volunteer support of physical education teachers who implement elements of sambo in the classroom. Master classes are held for teachers of educational organizations. 


\section{REFERENCES}

Aleksanyants, G. D., Grichanova, T. G., Dmitrenko, L. A. \& Sabirova, L. N. (2012). The use of some somatometric indicators for sports selection in table tennis. Fizicheskaya kul'tura, sport - nauka i praktika, no 2, pp. 37-40.

Afonina, I.P. (2012). Pedagogical conditions for the use of special preparatory exercises in the training of sambo fighters. Tula.

Babushkin, G. D., Shumilin, A. P. \& Salakhov, R. E. (2009). Reflection and intuition in the structure of the competitive activity of an athlete. Sportivnyy psikholog, no 3 (18), pp. 33-35.

Barchukov, I.S. \& Barchukova, G.V. (2014). Information technology in the selection of children in sports schools of table tennis. Moscow.

Boloban, V.N. \& Boloban, V.M. (2009). Elements of the theory and practice of sports orientation, selection and acquisition of groups in sports acrobatics. Pedagogika, psikhologiya i mediko-biologicheskiye problemy fizicheskogo vospitaniya i sporta, no 2, pp. 21-32.

Borschev, S. N. (2006). The effectiveness of the use of psychomotor testing techniques in the selection of primary school students for gymnastics. Fizicheskoye vospitaniye studentov tvorcheskikh spetsial'nostey, no 1, pp. 62-68.

Botyaev, V. L. (2015). Scientific and methodological support of selection in sports based on the assessment of coordination abilities. Moscow.

Daev, V. E (2007). Optimization of sports selection and orientation of football players by playing roles at the stage of in-depth specialization. Moscow.

Danilova, E.N. (2006). Individual properties of attention as a model characteristic of the role in sports selection in rugby. Herald of the KrasGAU, no 6, pp. 521-524.

Edgar D. Ramos, Timothy J. Pettit, Monika Flanigan, Luis Romero, Katherine Huayta, Inventory Management Model Based on Lean Supply Chain to Increase the Service Level in a Distributor of Automotive Sector , International Journal of Supply Chain Management (IJSCM), Vol 9, No 2 (2020), 113-131.

Egorenko, L.A. \& llyina, N.L. (2018). The theory and technique of rowing: a selection technique in rowing at all stages of preparation. St. Petersburg.

Gale lles and Oladipupo V. Adegun, Geography and Sentencing: Does Country of Citizenship Influence Sentence Longevity? - International Journal of Criminology and Sociology, 7, 2018, 48-58. https://doi.org/10.6000/1929-4409.2018.07.05

Ivankin, O.V. (2011). A comprehensive technique for the formation of the optimal combat state of young sambo wrestlers at the training stage. Tula.

Jean-François Yves Deluchey and Amanda Laysi Pimentel Dos Santos, Lethal Violence and Peripheral Youth Extermination in Brazil Amazon Region - International Journal of Criminology and Sociology, 2018, 7, 115-120. https://doi.org/10.6000/1929-4409.2018.07.16

Kargin, S.K. (2006). The methodology of selection and sports orientation of athletes-jumpers based on prognostic models. Volgograd.

Kashkin, A.A. (2000). The problem of the formation of special preparedness of young swimmers at the stages of long-term training. Moscow.

Kvashuk, P.V., Maslova, I.N. \& Verlina, E.V. (2010). Improving the selection system of talented children and adolescents for sports of the highest achievements Kul'tura fizicheskaya i zdorov'ye, no 3, pp. 70-72.

Koval, V.A. (2012). The problems of selection and training of high-level athletes in sports archery. Slobozhans'kiy naukovo-sportivniy vísnik, no 5-2 (33), pp. 36-40. 
Kokorina, E.A. (2007). Morphological and functional characteristics as criteria for sports selection in aerobics. St. Petersburg.

Kopysova, L.V. (2002). A comprehensive assessment of motor abilities in the process of initial selection of children for specialized occupations in sports games (for example, basketball). St. Petersburg.

Korolev, G.I. (2009). Methodology for the selection of young men in race walking at the stages of a longterm training process. Herald of sports science, no 4, pp. 9-12.

Kushch, N.V. (2004). The psychological and pedagogical heritage of William Stern and its significance for developmental and educational psychology. Nizhny Novgorod.

Levitsky, A.G. (2003). Management of the process of training judokas, taking into account the level of individual readiness for competitive activity. St. Petersburg.

Makaridin, D.N. (2006). Model characteristics of the strongest athletes in karate (WKF) in connection with the problem of sports selection. Theory and Practice of Physical Culture, no 7, pp. 36-39.

Martynenko, A.N. (2002). The development of decisiveness among sambo wrestlers at the stage of initial sports specialization. Omsk.

Medvedeva, E.N., Gaibov, F.F. \& Terekhin, V.S. (2013). To substantiate the need to increase the effectiveness of sports orientation and selection at the initial stage of training in gymnastic disciplines. Uchenye Zapiski universiteta im. P.F. Lesgaft, no 11 (105), pp. 94-98. https://doi.org/10.5930/issn.1994-4683.2013.11.105.p94-98

Mohsen Kosari, The composition of the board of directors and the structure of capital in banks In the Tehran Stock Exchange, Journal of Management and Accounting, Vol 6, No 04 (2018), 93-101.

Noskova, O.G. (2006). Moscow School of Industrial Psychotechnics (On the 115th anniversary of I. N. Shpilrein and the 110th anniversary of S. G. Gellerstein). Metodologiya i istoriya psikhologii, no 2(1), pp. 41-46.

Ostapenko, A.A. \& Yankovskaya, N.A. (2014). Transition to the new educational system: readiness and route (on the example of the transition from elementary school to primary). Shkol'nyye tekhnologii, no 1 , pp. 48-52.

Pavlov, V.I., Tarasov, V.A. \& Panina, O.V. (2008). An experimental model for the selection of beginners among university students for kettlebell lifting. Uchenye Zapiski universiteta im. P.F. Lesgaft, no 10 (44), pp. 76-79.

Pavlova, E.V. (2008). Improving the system of sports selection in rhythmic gymnastics based on indicators of development of coordination abilities. Surgut.

Panchenko, S. L. \& Panachev, V. D. (2009). An innovative method of selecting shooters from a rifle to a sports development group. Uchenye Zapiski universiteta im. P.F. Lesgaft, no 10 (56), pp. 80-83.

Peredelsky, A.A. (2016). The problem of early selection in sports and extreme aspects of its solution. Ekstremal'naya deyatel'nost' cheloveka, no 1 (38), pp. 62-67.

Platonov, V. \& Bolshakova, I. (2013). Forcing the long-term training of athletes and youth Olympic games. Science in Olympic Sports, no 2, pp. 37-42.

Rapoport, O. A. (2005). Integration of physical and psychological training of sambo wrestlers at the stage of initial sports specialization. Novokuznetsk.

Robert Werling, Sriram Chintakrindi, Nicholas Clark, Gregory Morris, Mark Perry, Blake Randol, Citizen Opinion Survey: How a Mid-Sized California Community Perceives their Police Department International Journal of Criminology and Sociology, 7, 2018, 239-249. https://doi.org/10.6000/19294409.2018.07.17

Saber, I.A. \& Kublanov, M.M. (2009). An innovative approach to the selection of shooter-gunners in the group of sports improvement. Fizicheskaya kul'tura: vospitaniye, obrazovaniye, trenirovka, no 5, pp. 34-37. 
Samsonov, M.M. (2011). On the issue of sports selection in complex sports (for example, summer polyathlon). Bulletin of the Tambov University. Series: Humanities, no 9 (101), pp. 74-78.

Sarjono H, Fernandez J, Jeremaiah R, Tjhie R, Simamora H, Integration of Quantity Discount Pricing into Newsvendor Model, International Journal of Supply Chain Management (IJSCM), Vol 9, No 2 (2020), 28-35.

Semenov, E.N., Sukhanova, E.V., Godunova, N.I., Irkhina, E.N. \& Markina, V. B. (2016). Morphological foundations of sports selection and determining the playing role of basketball players. Physical Culture and Health, no 5 (60), pp. 52-56.

Semenova, G.I., Tikhonov, G.G. \& Yakov, Yu.V. (2013). The specifics of the selection of athletes for the formation of sports tourism teams in the group of disciplines "routes". Omsk Scientific News. Series: Society. Story. Modernity, no 1 (115), pp. 151-155.

Sepehri Z., Sheikhalizadeh M., Descriptions and overall safety status of sport fields in schools of Ardabil city,Iran, Journal of Social Sciences and Humanities Research 7(2) (2019) 1-5.

Sergienko, L.P. (2013). Sports selection: theory and practice. Moscow.

Simen, V.P. \& Drandrov, G.L. (2016). Improving the technique of sports selection of weight lifters at the stage of initial training. Bulletin of the Chuvash State Pedagogical University named after I. Ya. Yakovleva, no 1 (89) pp. 146-152.

Suleymanov, N.L. (2016). Sports selection of weightlifters in the system of long-term training. Volgograd.

Shegelman, I.R. (2015). The concept of using elements of the national martial arts "sambo" as additional standards for passing the RLD standards. Obrazovatel'naya sreda segodnya: strategii razvitiya, no 1 (2), pp.441-443.

Shegelman, I.R., Kirilina,V., M. \& Godinov, A. N. (2019). The use of simulators in the process of training a national sport - sambo. Perspektivy nauki, no. 11 (122), pp.159-161.

Talibov, A. Kh., Gushchina, N.V., Lyashenko, O.V. \& Dmitrieva, E.S. (2019). The dynamics of the health status and physical development of athletes in the process of long-term training. Teoriya i praktika fizicheskoy kul'tury, no 4, pp. 102-104.

Umarov, M.K. (2014). Formation of the logical components of technical and tactical actions in martial arts on the basis of sambo. Bulletin of Moscow State Forest University, no 4(18), pp. 241-245.

Yakushev, D.S. (2014). Methods of selecting children 8-9 years old for orienteering on the basis of assessing the level and significance of the components of their integrated preparedness. Tula.

Zatsiorsky V.M. (2009). Physical qualities of an athlete: the basics of the theory and methods of education. Moscow: Soviet Sport.

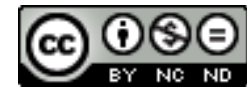

This work is licensed under a Attribution-NonCommercial-NoDerivatives 4.0 International (CC BY-NC-ND 4.0). 